\title{
Reconciliation of the Early Slip History of the Altyn Tagh Fault, Northern Tibetan
}

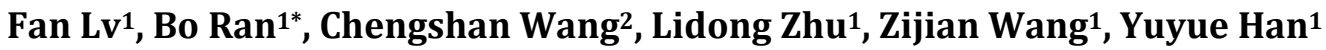 \\ ${ }^{1}$ State Key Laboratory of Oil and Gas Reservoir Geology and Exploitation, Chengdu University of Technology, Chengdu, China \\ ${ }^{2}$ State Key Laboratory of Biogeology and Environmental Geology, School of Earth Sciences and Resources, Research Center for \\ Tibetan Plateau Geology, China University of Geosciences (Beijing), Beijing, China \\ Email: *ranbo08@cdut.cn
}

How to cite this paper: Lv, F., Ran, B., Wang, C.S., Zhu, L.D., Wang, Z.J. and Han, Y.Y. (2019) Reconciliation of the Early Slip History of the Altyn Tagh Fault, Northern Tibetan. Open Journal of Geology, 9, 677-679.

https://doi.org/10.4236/ojg.2019.910073

Received: August 17, 2019

Accepted: September 22, 2019

Published: September 25, 2019

Copyright (C) 2019 by author(s) and Scientific Research Publishing Inc. This work is licensed under the Creative Commons Attribution International License (CC BY 4.0).

http://creativecommons.org/licenses/by/4.0/

\begin{abstract}
Whether the Altyn Tagh fault (ATF) had been extended beyond its current northeastern tip and linked with strike-slip faults in East Asia is a key to understanding the timing and mechanisms of crustal deformation in the northern Tibetan Plateau. We present Late Cretaceous dextral movement affected by Okhotomorsk Block-East Asia collision and a larger sinistral offset since Late Eocene along the ATF based on the provenance analysis of western Jiuxi Basin. Moreover, currently available estimates of offset based on displaced Paleozoic and Jurassic rocks could not represent the maximum offset due to late Cretaceous dextral offset.
\end{abstract}

\section{Keywords}

Altyn Tagh Fault, Jiuxi Basin, Basin Inversion, Cross-Fault Sediment/Source Match, Dextral Strike-Slip

\section{Introduction}

Large scale displacement and associated crustal thickening along the Altyn Tagh fault (ATF) have exerted a crucial influence on the geology and geography of Tibetan plateau. Although the modern ATF terminates near the Jiuxi Basin, its eastward extension in early slip history is the debate focus [1] [2], which is a key to understanding the timing and mechanisms of crustal deformation in the northern Tibetan plateau.

Furthermore, sedimentary basins adjacent to the ATF have been subjected to Early Cretaceous widespread extension and early Late Cretaceous significant inversion, and Late Cretaceous sequence is missing. Similarly, rift basins experienced analogical inversion in East Asia affected by Paleo-Pacific tectonism 
during the early Late Cretaceous, such as Yin-Er Basin, East Gobi Basin, Erlian Basin and Songliao Basin, etc. Yang [3] proposed a dextral strike-slip fault system in North China due to the collision of the Okhotomorsk Block with East Asia. In addition, right-lateral movement has been recognized after tectonic inversion in East Gobi Fault Zone [4]. If ATF could extend beyond the Tibetan Plateau and link with strike-slip faults in East Asia, its nature in late Cretaceous will be redefined.

\section{Approach and Result}

In this study, we investigated sediment source variation in western Jiuxi Basin before and after tectonic inversion. Paleocurrent directions towards the SE-SW in the field, indicating evince sediment main derivation from the opposing side of the ATF. So considering possible strike-slip displacement, potential sediment sources are mountains on the north side of ATF, including Beishan, Dunhuang and Altyn Blocks. Besides, Qilian shan is usually regarded as one of the most important provenance of the Jiuxi Basin.

In terms of Early Cretaceous Samples from the Hongliuxia area, detrital garnet and rutile composition both indicate middle and high grade metamorphic rocks exposed in the provenance. Moreover, a single $\mathrm{U}-\mathrm{Pb}$ peak age of detrital monazite is at ca. 375 - $440 \mathrm{Ma}$ and 20 - $40 \mathrm{Ma}$ younger than the early Paleozoic peaks of detrital zircon, matching with the timing of metamorphic events in the Dunhuang Block [5].

Late Eocene detrital zircon separated from Hongliuxia and Huoshaogou area are characterized by the absence of Paleozoic and Mesozoic ages, these materials are mainly derived from the Neoproterozoic basement in southern margin uplift of the Xorkol Basin and eastern tectonic melange zone of North Altyn Area [6] [7].

\section{Tectonic Implications}

1) The results of provenance analysis show Late Cretaceous dextral movement and $>450 \mathrm{~km}$ sinistral offset since Late Eocene along the eastern ATF near Jiuxi Basin. Relatively, larger sinistral offset along the middle part of ATF means that currently available estimates of offset based on displaced Paleozoic and Jurassic rocks could not represent maximum offset which weakened by late Cretaceous dextral offset.

2) Early Late Cretaceous basins inversion and Late Cretaceous dextral movement along ATF are dominated by the far-field effects of Okhotomorsk Block-East Asia collision during ca 100 - 80 Ma.

\section{Acknowledgements}

This work was funded by the National Natural Science Foundation of China (No. 41102064). This is a contribution to UNESCO-IUGS IGCP Project 679. 


\section{Conflicts of Interest}

The authors declare no conflicts of interest regarding the publication of this paper.

\section{References}

[1] Webb, L.E. and Johnson, C.L. (2006) Tertiary Strike-Slip Faulting in Southeastern Mongolia and Implications for Asian Tectonics. Earth and Planetary Science Letters, 241, 323-335. https://doi.org/10.1016/j.epsl.2005.10.033

[2] Cheng, F., Garzione, C., Jolivet, M., Wang, W., Dong, J., Richter, F. and Guo, Z. (2019) Provenance Analysis of the Yumen Basin and Northern Qilian Shan: Implications for the Pre-Collisional Paleogeography in the NE Tibetan Plateau and Eastern Termination of Altyn Tagh Fault. Gondwana Research, 65, 156-171. https://doi.org/10.1016/j.gr.2018.08.009

[3] Yang, Y.T. (2013) An Unrecognized Major Collision of the Okhotomorsk Block with East Asia during the Late Cretaceous, Constraints on the Plate Reorganization of the Northwest Pacific. Earth-Science Reviews, 126, 96-115.

https://doi.org/10.1016/j.earscirev.2013.07.010

[4] Prost, G.L. (2004) Tectonics and Hydrocarbon Systems of the East Gobi Basin, Mongolia. AAPG bulletin, 88, 483-513. https://doi.org/10.1306/11150303042

[5] Wang, H.Y., Chen, H.X., Zhang, Q.W., Shi, M.Y., Yan, Q.R., Hou, Q.L., et al. (2017) Tectonic Mélange Records the Silurian-Devonian Subduction-Metamorphic Process of the Southern Dunhuang Terrane, Southernmost Central Asian Orogenic Belt. Geology, 45, 427-430. https://doi.org/10.1130/G38834.1

[6] Gehrels, G.E., Yin, A. and Wang, X.F. (2003) Detrital-Zircon Geochronology of the Northeastern Tibetan Plateau. Geological Society of America Bulletin, 115, 881-896. https://doi.org/10.1130/0016-7606(2003)115<0881:DGOTNT>2.0.CO;2

[7] Li, P.Q. (2017) The Study on the Material Composition, Tectonic Deformation and Metallogenic Characteristics of Ophiolitic Tectonic Mélange Belt in Annan Dam Area, Altyn. MA Eng. Thesis, China University of Geosciences, Beijing. 